\title{
SEXUAL TRANSMISSION OF HEPATITIS C VIRUS
}

\author{
Fátima Mitiko Tengan(1), José ElUf-NETO(2), Norma de Paula CAVALHEIRO(3) \& Antonio Alci BARONE(1)
}

\begin{abstract}
SUMMARY
In order to contribute to a better understanding of the forms of acquisition of hepatitis $\mathrm{C}$ virus (HCV) in Brazil, with special emphasis on sexual transmission, we determined the presence of HCV infection in regular partners and in non-sexual home communicants of blood donors seen at Fundação Pró-Sangue Hemocentro de São Paulo from January 1992 to July 1996. Of 154 blood donors with HCV infection (index cases), 111 had had regular partners for at least 6 months. Sixty-eight of 111 partners were evaluated for HCV infection. Of these, $8(11.76 \%)$ were considered to have current or previous HCV infection; a history of sexually transmissible diseases and index cases with a positive HCV-RNA test were more prevalent among partners with HCV infection. Of the 68 index cases whose partners were studied, 56 had non-sexual home communicants. Of the total of 81 home communicants, 66 accepted to be evaluated for HCV infection. None of them was HCV-positive, suggesting that the high prevalence of HCV infection among partners may be attributed at least partially to sexual transmission.
\end{abstract}

KEYWORDS: Hepatitis C; Hepatitis C virus; Transmission; Sexual transmission; Prevalence study.

\section{INTRODUCTION}

The hepatitis $\mathrm{C}$ virus (HCV) is universally distributed and sporadic infection or infection acquired in the community may occur in individuals with no defined risk, a fact leading to the proposal of possible less obvious routes of transmission. Even before the identification of $\mathrm{HCV}$, a casecontrol study ${ }^{2}$ conducted in the United States suggested that heterosexual transmission may play a role in the dissemination of hepatitis non-A, non-B virus. In further studies highly conflicting data were obtained in estimates of the prevalence of HCV infection among heterosexual partners, with MEISEL et al. ${ }^{20}$ and POWER et al. ${ }^{28}$ finding no sign of sexual transmission while others ${ }^{1,5,16,26}$ reported findings compatible with heterosexual transmission of $\mathrm{HCV}$.

Few data are available in Brazil about this topic. Particularly important was the study by SOUTO et al. ${ }^{32}$ who, when evaluating the risk factors for $\mathrm{HCV}$ acquisition among 780 inhabitants of the southern Amazon region, found no signs that sexual activity contributed to the $2.4 \%$ prevalence of anti-HCV antibody-positive individuals found in this region. The objective of the present study was to contribute to the understanding of the forms of acquisition of HCV infection in Brazil, with special emphasis on sexual transmission.

\section{MATERIAL AND METHODS}

Study population: From January 1, 1992 to July 31, 1996, regular partners and non-sexual home communicants of blood donors (index case) infected with HCV who were seen at the Hepatitis Outpatient Clinic of the Infectious Diseases Clinic of the University Hospital, Faculty of Medicine of the University of São Paulo (UH-FMUSP), were investigated for the presence of $\mathrm{HCV}$ infection.

$\mathrm{HCV}$ infection was defined on the basis of the detection of anti$\mathrm{HCV}$ antibodies in blood by an immunoenzymatic method (ELISA) and by the recombinant immunoblot method (RIBA), or of anti-HCV antibodies by ELISA plus the presence of HCV-RNA in blood detected by the nested polymerase chain reaction (nested PCR). An index case was defined as a blood donor of Fundação Pró-Sangue Hemocentro de São Paulo, the largest blood bank in Brazil, with HCV infection who had been referred to the Hepatitis Outpatient Clinic of the Infectious Diseases Clinic of UH-FMUSP and who had a regular partner. A regular partner was defined as any person with whom the index case had been having regular sex relations for at least six months regardless of marital status. A non-sexual home communicant was defined as a person with whom the index case had been living for at least six months without ever having sexual relations. Only the home communicants of index cases whose partners could be studied were invited to participate. Regular partners and home communicants were invited for investigation of $\mathrm{HCV}$ infection only when the index case gave his consent. Of the 111 index cases selected for the study, 25 refused to tell their relatives that they had HCV infection; 86 partners were invited to participate in the study.

Data and material collection: Regular partners were privately interviewed by two persons who, using a standardized questionnaire,

\footnotetext{
(1) Infectious Diseases Department, Faculty of Medicine of the University of São Paulo, SP, Brasil.

(2) Preventive Medicine Department, Faculty of Medicine of the University of São Paulo, SP, Brasil.

(3) Hepatology Laboratory, Faculty of Medicine of the University of São Paulo, SP, Brasil.

Correspondence to: Fátima Mitiko Tengan, Av. Diederichsen 990, Apto. 171, 04310-000 São Paulo, SP, Brazil. Tel/Fax: (011) 5589 3185. e-mail: tengan@ sti.com.br
} 
obtained information about a history of parenteral exposure (such as blood transfusion, use of intravenous drugs, tattoos, acupuncture), data related to sexual behavior with the index case and intrafamily contact with individuals with a history of hepatitis. Home communicants were similarly interviewed by two persons who obtained the same information as listed above, except those related to sexual behavior, plus the time of cohabitation with the index case. Blood samples were collected from each participant in the study and the sera were stored at $-20{ }^{\circ} \mathrm{C}$ and only thawed when needed for the tests under study.

Laboratory tests: Anti-HCV antibody tests were performed by ELISA using a second-generation HCV EIA kit (Abbott) and by the recombinant immunoblot method using a Chiron RIBA HCV 3.0 SIA kit according to manufacturer instructions. HCV-RNA was investigated by nested PCR using two sets of nucleotide primers from 5' non-coding region ${ }^{11,12}$. Primers PTC1 and NCR2 were designated for the outer reaction. PTC3 and NCR4 were designated for the nested reaction. Nucleotide sequences were as follows:

\section{PTC1- 5' CGT TAG TAT GAG TGT CGT G3' \\ NCR2- 5' ATA CTC GAG GTG CAC GGT CTA CGA GAC CT3' PTC3-5' AGT GTC GTG CAG CCT CCA GG3' NCR4-5' CAC TCT CGA GCA CCC TAT CAG GCA GT3'}

The serologic studies were carried out at the UH-FMUSP and at the Hepatology Laboratory of FMUSP.

Statistical analysis: We calculated the proportion of persons with $\mathrm{HCV}$ infection among the sex partners of patients with HCV infection. In addition, we compared the potential risk factors for $\mathrm{HCV}$ acquisition between regular $\mathrm{HCV}$-infected partners and regular non-HCV-infected partners. Statistical analysis was performed using the $\chi^{2}$ test with Yates correction when necessary or by the exact Fisher test for smaller groups. Trend tests were applied by categorizing the exposure variables and considering the scores as continuous. Differences were considered to be significant when $\mathrm{p} \leq 0.05$. We also calculated the proportion of HCVinfected persons among the non-sexual home communicants of HCVinfected patients.

Ethical aspects: The study was approved by the Ethics Committee of our Institution and all participants gave written informed consent to participate.

\section{RESULTS}

1. Partners: Of the 86 partners invited to participate in the study, 16 refused and two were hospitalized (one with cerebral hemorrhage and the other due to chronic alcohol ingestion). Thus, 68 regular partners participated in the study. Ten partners $(14.5 \%)$ were positive to the antiHCV ELISA, but only $8(11.76 \%)$ were positive to the anti-HCV RIBA. The two partners with a negative anti-HCV RIBA result were also negative for HCV-RNA. Another partner whom we considered not to be infected with HCV showed an inconclusive anti-HCV ELISA result (2 samples) and a positive anti-HCV RIBA result (two samples).

1.1 Index cases: Table 1 shows the characteristics of the index cases whose partners were $\mathrm{HCV}$-infected compared to the index cases whose partners were HCV-negative. An index case with positive HCV-RNA was more frequent among $\mathrm{HCV}$-infected partners $\left(\chi^{2}=6.49 ; \mathrm{p}=0.005\right)$.
1.2 Infection with hepatitis $\mathrm{C}$ virus: Of the partners studied, 19 (27.9\%) were males and $49(72.1 \%)$ were females; mean age was 39.2 years and median age was 39.5 years (range: 17 to 63 ). Among HCVinfected partners, three $(37.5 \%)$ were males and five $(62.5 \%)$ were females; mean age was 39.6 years (range: 21 to 50). Table 2 shows the distribution of partners in terms of selected factors not related to sexual behavior. There was no difference in the frequency of these factors between the two groups studied. Table 3 shows the distribution of partners in terms of factors related to sexual behavior. Partners with a history of STD were more frequent in the groups of $\mathrm{HCV}$-infected partners than in the groups of non-infected partners $\left(\chi^{2}=4.72 ; p=0.02\right)$.

2. Home communicants: Of the 68 index cases whose partners were studied, 56 had non-sexual home communicants. Eighty-one home communicants of these 56 index cases were invited to participate in the study and 15 of them refused to participate. Table 4 shows the epidemiological characteristics of the home communicants studied. Thus, 66 home communicants were evaluated for $\mathrm{HCV}$ infection and none of them was HCV-positive.

\section{DISCUSSION}

In the present study we detected $11.76 \%$ of partners having current or past $\mathrm{HCV}$ infection. If two partners with a history of parenteral exposure (blood transfusion and use of injectable drugs) are excluded, the prevalence of $\mathrm{HCV}$ falls to $8.82 \%$. These eight HCV-positive partners had no history of exposure to blood transfusion, use of injectable drugs, tattoos or acupuncture. Thus, $80 \%$ of HCV-infected partners would appear not to have, at least explicitly, a known mode of HCV acquisition. The prevalence described $(8.82 \%)$ is undoubtedly modest compared to other studies of hepatitis B and human immunodeficiency virus, but this prevalence is about four-fold higher than that reported for blood donors of Fundação Pró-Sangue Hemocentro de São Paulo ${ }^{29}$, and four- to 12-

Table 1

Distribution of partners with respect to the characteristics of the index case

\begin{tabular}{lrrl}
\hline \multirow{2}{*}{$\begin{array}{l}\text { Characteristics of } \\
\text { the index case }\end{array}$} & $\mathrm{HCV}^{2}(+)$ & $\mathrm{HCV}^{2}(-)$ & $\mathrm{p}$ \\
\hline Blood transfusion $^{1}$ & 7 & 43 & \\
$\quad$ No & 1 & 17 & 0.60 \\
$\quad$ Yes & & & \\
Use of injectable drugs $^{1}$ & 60 & 55 & \\
$\quad$ No & 0 & 5 & 0.06 \\
$\quad$ Yes & & & \\
Tattoos $^{1}$ & 60 & 57 & \\
$\quad$ No & 0 & 3 & 0.24 \\
$\quad$ Yes & & & \\
Acupuncture & & & \\
$\quad$ No & 60 & 57 & \\
$\quad$ Yes & 0 & 3 & 0.24 \\
HCV-RNA & & & \\
$\quad$ Negative & 0 & 33 & \\
$\quad$ Positive & 8 & 27 & 0.005 \\
\hline
\end{tabular}

${ }^{1}$ Antecedent; ${ }^{2}$ Infection with hepatitis $\mathrm{C}$ virus. 
Table 2

Distribution of partners with respect to selected factors, except those related to sexual behavior

\begin{tabular}{|c|c|c|c|}
\hline \multirow{2}{*}{$\begin{array}{l}\text { Characteristics of } \\
\text { the partner }\end{array}$} & \multicolumn{2}{|c|}{ Partner } & \multirow[b]{2}{*}{$\mathrm{p}$} \\
\hline & $\mathrm{HCV}^{2}(+)$ & $\mathrm{HCV}^{2}(-)$ & \\
\hline \multicolumn{4}{|l|}{ Blood transfusion $^{1}$} \\
\hline No & 7 & 57 & \\
\hline Yes & 1 & 3 & 0.40 \\
\hline \multicolumn{4}{|c|}{ Use of injectable drugs ${ }^{1}$} \\
\hline No & 7 & 60 & \\
\hline Yes & 1 & 0 & 0.12 \\
\hline \multicolumn{4}{|l|}{ Tattoos $^{1}$} \\
\hline No & 8 & 60 & \\
\hline Yes & 0 & 0 & - \\
\hline \multicolumn{4}{|l|}{ Acupuncture $^{1}$} \\
\hline No & 8 & 60 & \\
\hline Yes & 0 & 0 & - \\
\hline \multicolumn{4}{|c|}{ Home contact with a person } \\
\hline \multicolumn{4}{|c|}{ with a history of blood transfusion ${ }^{1}$} \\
\hline Yes & 0 & 3 & 1.0 \\
\hline \multicolumn{4}{|c|}{$\begin{array}{l}\text { Home contact with a person with a } \\
\text { history of use of injectable drugs }{ }^{1}\end{array}$} \\
\hline No & 8 & 58 & \\
\hline Yes & 0 & 2 & 1.0 \\
\hline
\end{tabular}

Table 3

Distribution of partners with respect to factors related to sexual behavior

\begin{tabular}{|c|c|c|c|}
\hline \multirow{2}{*}{$\begin{array}{l}\text { Characteristics of } \\
\text { the partner }\end{array}$} & \multicolumn{2}{|c|}{ Partner } & \multirow[b]{2}{*}{$\mathrm{p}$} \\
\hline & $\mathrm{HCV}^{1}(+)$ & $\mathrm{HCV}^{1}(-)$ & \\
\hline \multicolumn{4}{|c|}{ Duration of the relationship (years) } \\
\hline $0-1$ & 1 & 9 & \\
\hline $2-5$ & 2 & 7 & \\
\hline $6-10$ & 0 & 9 & \\
\hline $10-20$ & 2 & 21 & \\
\hline$\geq 20$ & 3 & 14 & \\
\hline$\chi^{2}$ trend $=1.57$ & & & 0.21 \\
\hline \multicolumn{4}{|l|}{ History of STD } \\
\hline No & 3 & 48 & \\
\hline Yes & 5 & 12 & 0.02 \\
\hline \multicolumn{4}{|l|}{ Use of condoms } \\
\hline Never & 7 & 52 & \\
\hline Occasionally & 1 & 4 & \\
\hline Most of the times & 0 & 1 & \\
\hline Always & 0 & 3 & \\
\hline$\chi^{2}$ trend $=0.23$ & & & 0.63 \\
\hline \multicolumn{4}{|c|}{ Number of relations/month } \\
\hline $1-3$ & 1 & 9 & \\
\hline $4-5$ & 0 & 14 & \\
\hline $6-10$ & 4 & 21 & \\
\hline$>10$ & 3 & 16 & \\
\hline$\chi^{2}$ trend $=1.04$ & & & 0.31 \\
\hline \multicolumn{4}{|l|}{ Number of partners } \\
\hline 1 & 6 & 30 & \\
\hline $2-3$ & 0 & 14 & \\
\hline $4-10$ & 0 & 3 & \\
\hline$>10$ & 2 & 13 & \\
\hline$\chi^{2}$ trend $=0.26$ & & & 0.61 \\
\hline
\end{tabular}

${ }^{1}$ Infection with hepatitis $\mathrm{C}$ virus
Table 4

Epidemiological characteristics of 66 non-sexual home communicants of blood donors with HCV infection

\begin{tabular}{|c|c|}
\hline Characteristics of the Home communicant & $\begin{array}{c}\text { Number of } \\
\text { Communicants }\end{array}$ \\
\hline Male sex $(\%)$ & $23(34.8 \%)$ \\
\hline $\begin{array}{l}\text { Age (years) } \\
\text { Mean } \\
\text { Median } \\
\text { Range }\end{array}$ & $\begin{array}{l}25.0 \\
16.5 \\
3-73\end{array}$ \\
\hline $\begin{array}{l}\text { Transfusion of blood and/or blood components }{ }^{1}(\%) \\
\text { No } \\
\text { Yes }\end{array}$ & $\begin{array}{l}54(81.8) \\
12(18.2)\end{array}$ \\
\hline $\begin{array}{l}\text { Injectable illicit } \operatorname{drug}^{1}(\%) \\
\text { No } \\
\text { Yes }\end{array}$ & $\begin{array}{c}66(100) \\
0(0)\end{array}$ \\
\hline $\begin{array}{l}\text { Acupuncture }^{1}(\%) \\
\text { No } \\
\text { Yes }\end{array}$ & $\begin{array}{c}66(100) \\
0(0)\end{array}$ \\
\hline $\begin{array}{l}\text { Tattoos }^{1}(\%) \\
\text { No } \\
\text { Yes }\end{array}$ & $\begin{array}{c}66(100) \\
0(0)\end{array}$ \\
\hline $\begin{array}{l}\text { Health professional }{ }^{1}(\%) \\
\text { No } \\
\text { Yes }\end{array}$ & $\begin{array}{c}66(100) \\
0(0)\end{array}$ \\
\hline $\begin{array}{l}\text { Time of cohabitation (years) with the index case }(\%) \\
\quad<5 \\
\quad 5-10 \\
11-20 \\
21-30 \\
<30\end{array}$ & $\begin{array}{c}10(15.2) \\
17(25.8) \\
21(31.8) \\
12(18.2) \\
6(9.0)\end{array}$ \\
\hline
\end{tabular}

${ }^{1}$ Antecedent

fold higher than the estimated prevalence of HCV infection in the municipality of São Paulo?.

Another hypothetical mode of HCV acquisition would be through the sexual route, especially if we consider that having an HCV-RNApositive spouse (index case) and having a history of STD were more frequent in the group of positive partners than in the group of negative partners. Although the epidemiological importance of sexual HCV transmission is not clear, this type of transmission could explain at least in part this increased frequency in positive partners since the detection of HCV-RNA in semen reported in some studies ${ }^{17,18,19}$ represents evidence of a biologically plausible possibility of sexual transmission. In other studies, high rates of $\mathrm{HCV}$ infection were detected among persons with multiple sex partners and among sex professionals ${ }^{7,22,33}$. In Japan ${ }^{22}$, the prevalence among female prostitutes $(6.2 \%)$ was similar to that observed in STD clinics (6.1\%), but higher than that among blood donors (1.5\%). In case-control studies on subjects with chronic HCV infection, risk factors related to sexual behavior such as a history of $\mathrm{STD}^{6,31}$, sex with prostitutes or having had more than five sex partners during the last year ${ }^{6}$ were significantly associated with $\mathrm{HCV}$ infection. In another casecontrol study ${ }^{30}$ conducted in Spain, the prevalence of HCV infection 
among pregnant women increased with total number of partners, being 14-fold higher among women with more than four partners than among pregnant women with only one partner.

The association between the status of HCV infection and a history of STD leads us to think about some mechanism of facilitation of HCV acquisition. Low HCV-RNA in blood and secretions may explain the fact that some investigators ${ }^{17,18,19,25}$ detected the presence of HCV-RNA in fluids and secretions (saliva, urine, seminal fluid) while others ${ }^{10,15}$ did not detect it in vaginal secretion, semen or saliva. Under these circumstances of low "infectivity", an intact epithelium or local immunological factors probably play a role in the lack of HCV acquisition; with the presence of an STD, the epithelial defenses of the organisms may be broken, considerably increasing the susceptibility to HCV. Furthermore, HCV RNA has been previously detected in peripheral blood monocytes/macrophages of patients with chronic hepatitis $\mathrm{C}^{3,34}$. These cells are also found in vaginal secretions and in semen, and may be a source of HCV for sexual transmission. This same mechanism has been suggested to explain the transmission of Hepatitis B virus and of human immunodeficiency virus ${ }^{8,14}$. Other studies have also investigated the effect of the duration of the relationship with the index case. In Italy, PIPAN et al. ${ }^{27}$ detected a $16 \%$ (10/61) prevalence of HCV-infected longtime partners. The mean duration of the relationship was 29 years and the distribution of other risk factors for the acquisition of HCV infection did not differ between infected and non-infected groups. AKAHANE et $a l .{ }^{1}$ studied the wives of $\mathrm{HCV}$-infected patients in various stages of hepatic disease and detected a prevalence of $27 \%$. The infection was related to age and to duration of the relationship, being $0 \%$ for subjects with a relationship of 10 years or less and increasing to $32 \%$ for subjects with a relationship of 30 years or more. Logistic regression analysis showed an adjusted odds ratio of 1.5 for each decade of marriage (CI, 1.05-2.2). Similar infection rates were found in Taiwan studies ${ }^{4,16}$.

However, sexual transmission is difficult to prove since other routes of infection currently being discussed may be present between the members of a couple, such as the shared use of utensils that might cause lesions and virus transmission. This form of transmission, called intrafamily or intrahome transmission, has been suggested by some authors ${ }^{13,21,23,24}$, although others did not detect a higher prevalence of $\mathrm{HCV}$ infection among non-sexual home communicants than in the general population, as was the case in our study (of the non-sexual home communicants studied, none was HCV-infected). Unfortunately we were in no position to analyze the sequence of nucleotides of the HCV genome in couples with concordant infection. This study would be important since the high heterogeneity of HCV strains, and the detection of identical (or almost identical) nucleotide sequences would be strong evidence of a common source of infection, although it would not elucidate the direction in which infection occurred.

Finally, we understand that the major limitation of our study is the relatively small number of participants which did not permit us to test if certain variables (for example, "total number of partners", "duration of the relationship" and "use of condoms") could be associated with HCV infection, since the number of participants in each category defined a priori (Table 3) was insufficient. In order to obtain more consistent evidence, a larger number of index case partners with and without HCV infection would be necessary, and/or a follow-up of a larger number of HCV-communicant or non-communicant partners along time (presumably 20 to 30 years), so as to permit an evaluation of the incidence of $\mathrm{HCV}$ acquisition among these persons, with a more appropriate testing of the hypothesis of sexual transmission.

\section{RESUMO}

\section{Transmissão sexual do vírus da hepatite $\mathrm{C}$}

Com o objetivo de contribuir para o melhor entendimento das formas de aquisição do vírus da hepatite $\mathrm{C}$, em nosso meio, com especial atenção para a transmissão sexual, avaliamos a presença de infecção pelo vírus da hepatite $\mathrm{C}$ em parceiros regulares e comunicantes domiciliares não sexuais de doadores de sangue provenientes da Fundação Pró-Sangue Hemocentro de São Paulo, no período de janeiro de 1992 a julho de 1996. De 154 doadores de sangue com infecção pelo HCV (casosíndices), 111 tinham parceiros regulares, há pelo menos 6 meses. De 111 parceiros, 68 foram avaliados quanto à infecção pelo HCV. Desses, $8(11,76 \%)$ parceiros foram considerados como tendo infecção atual ou pregressa pelo HCV; história de DST e caso-índice com HCV-RNA positivo foi mais prevalente entre os parceiros com infecção pelo $\mathrm{HCV}$ do que entre os parceiros sem infecção pelo HCV. Dos 68 casos-índices, cujos parceiros foram estudados, 56 tinham comunicantes domiciliares não sexuais. Do total de 81 comunicantes domiciliares, 66 aceitaram ser avaliados quanto à infecção pelo HCV. Nenhum deles foi positivo para infecção pelo HCV, sugerindo que a alta prevalência de infecção pelo $\mathrm{HCV}$ entre os parceiros pode ser atribuída, pelo menos parcialmente, à transmissão sexual.

\section{ACKNOWLEDGMENTS}

The authors wish to thank Fundação Pró-Sangue Hemocentro de São Paulo, its staff, and Dr. Marcelo Cliquet for help with the present study.

\section{REFERENCES}

1. AKAHANE, Y.; KOJIMA, M.; SUGAI, Y. et al. - Hepatitis C virus infection in spouses of patients with type $C$ chronic liver disease. Ann. intern. Med., 120: 748-752, 1994.

2. ALTER, M.J.; COLEMAN, P.J.; ALEXANDER, W.J. et al. - Importance of heterosexual activity in the transmission of hepatitis B and non-A, non-B hepatitis. J. Amer. Med. Ass., 262: 1201-1205, 1989.

3. BOUFFARD, P.; HAYASHI, P.H.; ACEVEDO, R.; LEVY, N. \& ZELDIS, J.B. - Hepatitis $\mathrm{C}$ virus is detected in a monocyte/macrophage subpopulation of peripheral blood mononuclear cells of infected patients. J. infect. Dis., 166: 1276-1280, 1992.

4. CHANG, T.T.; LIOU, T.C.; YOUNG, K.C. et al. - Intrafamilial transmission of hepatitis C virus: the important role of inapparent transmission. J. med. Virol., 42: 91-96, 1994

5. CHAYAMA, K.; KOBAYASHI, M.; TSUBOTA, A. et al. - Molecular analysis of intraspousal transmission of hepatitis C virus. J. Hepat., 22: 431-439, 1995.

6. CONRY-CANTILENA, C.; VANRADEN, M.; GIBBLE, J. et al. - Routes of infection, viremia, and liver disease in blood donors found to have hepatitis $\mathrm{C}$ virus infection. New Engl. J. Med., 334: 1691-1696, 1996.

7. DAIKOS, G.L.; LAI, S. \& FISCHL, M.A. - Hepatitis C virus in a sexually active inner city population. The potential for heterosexual transmission. Infection, 22: 72-76, 1994. 
8. FAGAN, E.A.; SMITH, P.M.; DAVISON, F. \& WILLIAMS, R. - Fulminant hepatitis B in successive female sexual partners of two anti-Hbe-positive males. Lancet, 2: 538540,1986

9. FOCACCIA, R. - Prevalência das hepatite virais A, B, C e E. Estimativa de prevalência na população geral da cidade de São Paulo, medida por marcadores séricos, em amostragem populacional estratificada com sorteio aleatório e coleta domiciliar São Paulo, 1997. (Tese de Livre-Docência - Faculdade de Medicina da Universidade de São Paulo).

10. FRIED, M.W.; SHINDO, M.; FONG, T-L. et al. - Absence of hepatitis C viral RNA from saliva and semen of patients with chronic hepatitis C. Gastroenterology, 102: 1306$1308,1992$.

11. GARSON, J.A.; TEDDER, R.S.; BRIGGS, M. et al. - Detection of hepatitis C viral sequences in blood donations by "nested" polymerase chain reaction and prediction of infectivity. Lancet, 335: 1419-1422, 1990.

12. GARSON, J.A.; RING, C.; TUKE, P. \& TEDDER, R.S. - Enhanced detection by PCR of hepatitis C virus RNA. Lancet, 336: 878-879, 1990.

13. HAYASHI, J.; KISHIHARA, Y.; YAMAJI, K. et al. - Transmission of hepatitis C virus by health care workers in a rural area of Japan. Amer. J. Gastroent., 90: 794-799, 1995

14. HOOK, E.W. III.; CANNON, R.O.; NAHMIAS, A.J. et al. - Herpes simplex virus infection as a risk factor for human immunodeficiency virus infection in heterosexuals. J. infect. Dis., 165: 251-255, 1992.

15. HSU, H.H.; WRIGHT, T.L.; LUBA, D. et al. - Failure to detect hepatitis C virus genome in human secretions with the polymerase chain reaction. Hepatology, 14: 763-767, 1991.

16. KAO, J.H.; CHEN, P.J.; YANG, P.M. et al. - Intrafamilial transmission of hepatitis C virus: the important role of infections between spouses. J. infect. Dis., 166: 900903, 1992.

17. KOTWAL, G.J.; RUSTGI, V.K. \& BAROUDY, B.M. - Detection of hepatitis C virusspecific antigens in semen from non-A, non-B hepatitis patients. Dig. Dis. Sci., 37: 641-644, 1992.

18. LEVY, R.; TARDY, J.C.; BOURLET, T. et al. - Transmission risk of hepatitis C virus in assisted reproductive techniques. Hum. Reprod., 15: 810-816, 2000.

19. LIOU, T.C.; CHANG, T.T.; YOUNG, K.C. et al. - Detection of HCV RNA in saliva, urine, seminal fluid, and ascites. J. med. Virol., 37: 197-202, 1992.

20. MEISEL, H.; REIP, A.; FALTUS, B. et al. - Transmission of hepatitis C virus to children and husbands by women infected with contaminated anti-D immunoglobulin. Lancet, 345: 1209-1211, 1995.

21. NAKASHIMA, K.; IKEMATSU, H.; HAYASHI, J. et al. - Intrafamilial transmission of hepatitis $\mathrm{C}$ virus among the population of an endemic area of Japan. J. Amer. Med. Ass., 274: 1459-1461, 1995.
22. NAKASHIMA, K.; KASHIWAGI, S.; HAYASHI, J. et al. - Sexual transmission of hepatitis $\mathrm{C}$ virus among female prostitutes and patients with sexually transmitted diseases in Fukuoka, Kyushu, Japan. Amer. J. Epidem., 136: 1132-1137, 1992.

23. NISHIGUCHI, S.; KUROKI, T.; FUKUDA, K. et al. - Familial clustering of HCV. [Letter]. Lancet, 339: 1486, 1992.

24. NOGUCHI, S.; SATA, M.; SUZUKI, H.; MIZOKAMI, M. \& TANIKAWA, K. - Routes of transmission of hepatitis $\mathrm{C}$ virus in an endemic rural area of Japan. Molecular epidemiologic study of hepatitis C virus infection. Scand. J. infect. Dis., 29: 23-28, 1997

25. NUMATA, N.; OHORI, H.; HAYAKAWA, Y. et al. - Demonstration of hepatitis C virus genome in saliva and urine of patients with type $\mathrm{C}$ hepatitis: usefulness of the single round polymerase chain reaction method for detection of the HCV genome. J. med. Virol., 41: 120-128, 1993.

26. OSHITA, M.; HAYASHI, N.; KASAHARA, A. et al. - Prevalence of hepatitis C virus in family members of patients with hepatitis C. J. med. Virol., 41: 251-255, 1993.

27. PIPAN, C.; AMICI, S.; COLLE, R. \& BOTTA, G.A. - Intrafamilial transmission of hepatitis C virus. [Letter]. J. Infect., 29: 353-355, 1994.

28. POWER, J.P.; DAVIDSON, F.; O'RIORDAN, J. et al. - Hepatitis C infection from antiD immunoglobulin. [Letter]. Lancet, 346: 372-373, 1995.

29. SAEZ-ALQUEZAR, A. - Hepatitis C: aspectos epidemiológicos e metodologias. In: SIMPÓSIO NACIONAL DE ATUALIZAÇÃO EM HEPATITE C, 1., São Paulo, 1996. Anais. p. 13-21

30. SALLERAS, L.; BRUGUERA, M.; VIDAL, J. et al. - Importance of sexual transmission of hepatitis $\mathrm{C}$ virus in seropositive pregnant women: a case-control study. J. med. Virol., 52: 164-167, 1997

31. SHEV, S.; HERMODSSON, S.; LINDHOLM, A. et al. - Risk factor exposure among hepatitis C virus RNA positive Swedish blood donors: the role of parenteral and sexual transmission. Scand. J. infect. Dis., 27: 99-104, 1995.

32. SOUTO, F.J.D.; FONTES, C.J.F.; MARTELLI, C.M.T. et al. - Hepatitis C virus prevalence among an immigrant community to the Southern Amazon, Brazil. Mem. Inst. Oswaldo Cruz, 94: 719-723, 1999.

33. THOMAS, D.L.; ZENILMAN, J.M.; ALTER, H.J. et al. - Sexual transmission of hepatitis $\mathrm{C}$ virus among patients attending sexually transmitted diseases clinics in Baltimore. An analysis of 309 sex partnerships. J. infect. Dis., 171: 768-775, 1995.

34. YOUNG, K.C.; CHANG, T.T.; LIOU, T.C. \& WU, H-L. - Detection of hepatitis C virus RNA in peripheral blood mononuclear cells and saliva. J. med. Virol., 41: 55-60, 1993.

Received: 14 May 1999

Accepted: 08 March 2001 